\title{
BIVOLTINE SERICULTURE ENLARGEMENT IN VENKATAGIRI KOTA, CHITTOOR DISTRICT, ANDHRA PRADESH THROUGH CLUSTER PROMOTION PROGRAMME (CPP)-AN ACCOMPLISHMENT
}

\author{
S. Nazeer Ahmed Saheb', T. Mogili2, P.S. Reddy 3 , S. Sashank Reddy 4 , \\ P. Sudhakar ${ }^{5}$, B. Vijaya Naidu' ${ }^{6}$ and Pankaj Tewari ${ }^{7}$ \\ 5,6 Regional Sericultural Research Station, Central Silk Board (CSB), Ananthapur-515 001, Andhra Pradesh, India \\ 1,2,3 Research Extension Centre, CSB, V. Kota - 517 424, Chittoor District, Andhra Pradesh, India \\ ${ }_{4}^{4}$ Department of Sericulture, V. Kota - 517 424, Chittoor District, Govt. of Andhra Pradesh, India \\ ${ }^{7}$ Central Sericultural Research and Training Institute (CSRTI), CSB, Mysore-570 008, Karnataka, India
}

(Received on Date: 10 $0^{\text {th }}$ April 2020 Date of Acceptance: 14 May 2020 Date of Publish: $01^{\text {st }}$ July 2020 )

Email id: sudhakarcsb@rediffmail.com

\begin{abstract}
Cluster Promotion Programme (CPP) was implemented under XI \& XII five year plans during 2009-2019 in India for boosting the gradable quality bivoltine rawsilk production. Out of the 17 clusters in Andhra Pradesh, V. Kota has been recognised as one of the potential clusters under Chittoor District for the development of Bivoltine sericulture. Due to CPP implementation during the period 2009-2019, Bivoltine DFLs brushing was raised from the bench mark level (1.50 lakh) to progressive level of 2.43 lakh (2009-10), 2.61 (2010-11), 3.46 (2011-12), 9.00 (2012-13), 10.15 (2013-14), 11.55 (2014-15), 13.3 (2015-16), 15.1 (2016-17), 17.52 (2017-18), 20.66 (2018-19) with a total of 78.1 lakh DFLs as against the targeted 76.5 lakh DFLs among the 30,537 farmers in a span of 10 years. The percentage of achievement in regard to the DFLs distribution was ranging from 98.4 to $108.8 \%$ against the targeted DFLs during 2009 to 2019 and 62.0 to $1277 \%$ over the benchmark level of DFLs brushing before the initiation of CPP. In regard to the cocoon yield per 100 DFLs also improved at a significant level from $61.20 \mathrm{~kg}$ to $79.86 \mathrm{~kg}$ per $100 \mathrm{DFLs}$ with an average yield improvement of $73.3 \mathrm{~kg}$ cocoon per 100 DFLs during the CPP period. Cocoon yield was also significantly increased ranging from $27.50 \%$ to $66.38 \%$ as against the benchmark yield (48kg/100DFLs) with an average yield of $52.71 \%$ thereby increasing raw silk production from 20.11 MT to $213.59 \mathrm{MT} / \mathrm{year}$ with an average Bivoltine raw silk production of 581.6MT due to meticulous implementation of CPP in the cluster. With the committed efforts of CPP implementation team quality Bivoltine cocoons could fetch encouraging market rates ranging from Rs. 235/- to Rs. 336/- with an average market value of Rs. 373/- as compared to the bench mark rate (Rs. 230/-) prior to CPP implementation under V. Kota cluster. Therefore, CPP launching at V. Kota has not only improved the Bivoltine sericulture but also raised the morale and socio economic conditions of the sericulture farming community.
\end{abstract}

Key words: Mulberry cultivation, Sericulture, Silkworm rearing, Bivoltine cocoon, CPP, DFLs, 2020 July Edition | www.jbino.com | Innovative Association 


\section{INTRODUCTION}

Though, India stands 2 nd position in the world in production of raw silk but failing to compete in international market due to its non gradable quality silk production. Therefore, production of gradable quality bivoltine silk has become the prime agenda of Indian sericulture industry. In recent years though India has registered an impressive growth on the sericulture front, in terms of quality and productivity, yet it is often felt that there exists a gap in the yields between what the technologies could fetch the farmer and what he is actually getting. India being the largest consumer of natural silk in the world and demand for quality raw silk has been increasing in the country gradually over the years. The annual raw silk production was 20,410 MT in 2010-11 and did not suffice the actual requirements of the country. As a result, India had to import 5,870 MT of raw silk and 3780 MT silk fabrics (Himantharaj et al., 2012, Sudhakar et al., $2018,2019)$. As the demand-supply gap is widening in mulberry silk, there is urgent need to improve the production, productivity and quality of Indian raw silk for meeting the requirement for domestic market to become self-reliant by phasing out import of raw silk and compete in the international market especially in the changing scenario of the global trade. However, there is a major challenge to enact in this direction, that being over $90 \%$ of our production has upgradable quality. Ultimately to overcome with the present situation judicious efforts for increasing the bivoltine gradable silk production in the country is the solution.To pursue the goal of bivoltine sericulture development, a well organised and planned strategic extension system is very much essential for transfer of new bivoltine sericulture technologies so as to achieve the targeted production (Himantharaj et al., 2007; Jaishankar and Dandin., 2005). Emphasis on the effective extension communication mechanisms, percolation of cost-effective technologies that fit well into the region and followed by the better interaction and involvement of Scientists, extension and field functionaries towards the end users to identify, assess and find a solution to a problem. These kind of participatory approaches will definitely results in achieving the anticipated targets. In this direction many extension approaches such as Catalytic Development Programmes (CDP), Institute Village Linkage Programmes (IVLP) and Technology Validation and Development Progarmmes (TVDP) have adopted by the Central Sericultural Research and Training Institute (CSR\&TI), Mysore were adopted in sericulture for the transfer of technologies to the farmers from time to time with the support of State Sericulture Department and the results were encouraging (Sreenivas et al., 2010). Among them cluster development approach is one which is holistic, information based and participatory extension mode with Research-Extension-Farmer (R-E-F) linkage. This approach was effectively implemented in the farm of five year plans during 2009-12 for large scale promotion of bivoltine sericulture in India particularly in Southern major silk producing regions and the results was encouraging (Himantharaj et al., 2012, Qadri, 2012, Sudhakar et al., 2018).

2020 July Edition | www.jbino.com | Innovative Association 
The Cluster Promotion Programme (CPP) was implemented under XI \& XII five year plan during 2008-2019 in India for boosting the bivoltine sericulture development. The Central Silk Board (CSB) and State level Departments of Sericulture have jointly organised 178 clusters all over India i.e., 106 clusters in 5 states of Southern zone, 45 in 5 states of North-western zone, 11 in 3 states of Central Western Zone, 7 in 3 states of Eastern zone and 9 in 8 states of North Eastern zone, respectively. Out of 106 clusters in Southern India 46 clusters were implemented in Karnataka, 28 in Tamil Nadu, 17 in Andhra Pradesh, 4 in Maharashtra whereas 2 clusters in Kerala with an anticipated 167.06 lakh DFLs brushing and generate 1920MT of bivoltine raw silk. Among 17 clusters of Andhra Pradesh, Venkatagiri Kota popularly known as $V$. Kota fall around $100 \mathrm{kms}$ away from Chittoor District was considered to implement Cluster Promotion Programme (CPP) from April, 2009 to March, 2019 with the objectives to increase production and productivity of quality bivoltine sericulture effectively in Andhra Pradesh. V. Kota is a small town adjascent to Kuppam Mandal located at $13.00^{\circ} \mathrm{N} 78.50^{\circ} \mathrm{E}$ having an average elevation of 764 meters (2509 feet) above sea level. The village is very close to Karnataka and Tamil Nadu state borders indicating that $\mathrm{V}$. Kota is surrounded by the Traditional sericultural states. Sericulture is flourishing in the vicinity because of congenial atmosphere for silkworm rearing around the year. The area experiences annual average temperature recording $28^{\circ} \mathrm{C}$ with $14^{\circ} \mathrm{C}$ min. and $35^{\circ} \mathrm{C}$ max. offer amicable atmosphere for the silkworm rearing. Though, the cluster is very familiar with sericulture but non traditional for Bivoltine rearing. Therefore, production of gradable Bivoltine silk is our motto by replacing the $\mathrm{CB}$ rearing in the area. Hence, V. Kota was identified to implement cluster promotion programme for the development of Bivoltine sericulture.

\section{MATERIAL AND METHODS}

On the onset of Cluster Promotion Programme (CPP) implementation in $\mathrm{V}$. Kota during 2009-2019, a preliminary bench mark survey was conducted jointly by the Scientist and Dept. of Sericulture (DOS), $V$. Kota to understand the status of mulberry area, variety, spacing, rearing house and rearing facilities to quantify the requirement of farmers and also funds to meet the farmers requirements. It was revealed that most of the farmers were well versed with the cross breed (CB) silkworm rearing adopting poor and inadequate technologies in case of rearing as well as mulberry cultivation. The farmers were having mulberry gardens planted with poor yielding mulberry vars in closer spacing incorporating primitive cultivation technologies. The farmers were poor in technical knowhow and lacking proper guidelines to improve their practice. They were also lacking Governmental support either in case of mulberry cultivation or in silkworm rearing. The sericulturists of the vicinity use to brush cross breeds (CB) around more than $1,50,000$ DFLs annually and harvest $48 \mathrm{~kg}$ of cocoon per 100 DFLs fetching with a meager market rate of Rs.230/- per kg cocoon in the localized markets. Under the scenario Central Silk Board (CSB) in coordination with Department of 
Sericulture (DOS), Andhra Pradesh initiated the CPP approach in the villages where the sericulture families located nearby to impart CPP and popularize Bivoltine sericulture. The cluster promotion team such as CSB Scientists \& Technical staff and Officials \& field functionaries of the DOS as Cluster Development Facilitators (CDFs) adopted the enthusiastic sericulturists to impart Bivoltine sericulture among the existing as well as new farmers. In the CPP approach a cluster of villages and sericultural families located nearby were selected and adopted to have areas/mass effect of the improved technologies incorporated under the CPP so that the activities are manageable easily with the limited technical (Scientist \& Technical staff) and extension field functionaries jointly by the active involvement of local stake holders. Under CPP, contiguous villages within the radius of around $20-30 \mathrm{~km}$ are selected to save time and money on transport and to facilitate closer monitoring and interactions of scientist as well as field functionaries with cluster farmers and to ensure good and anticipated results. One village or a cluster of villages located nearby is selected such way that as far as possible eligible farmers of villages/cluster of villages are covered under the CPP (Sathyanarayana Raju et al., 2014; Sudhakar et al., 2019). Basing on the survey the assistance is provided to the farmers through Catalytic Development Programme (CDP) to strengthen the facilities, encourage and motivate the bivoltine sericulture farming under the cluster. To achieve the objective of Bivoltine sericulture development in the cluster CPP was effectively imparted with all the vital modalities as detailed by Sudhakar et al., 2018. The period of CPP implementation under $\mathrm{V}$. Kota cluster, impact study was conducted to analyze the impact of CPP on cocoon production quality, cocoon quality and economic benefit of the sericulturists were assessed and the results are presented.

\section{RESULTS AND DISCUSSIONS}

Before initiation of the Cluster Promotion Programme (CPP) a bench mark survey was conducted very meticulously during 2008-09 to assess the initial status of existence of bivoltine sericulture and the technical knowhow of the mulberry and sericulture farming in and around the $\mathrm{V}$. Kota cluster. Survey revealed that both bivoltine and cross breed (CB) silkworm rearing to a nominal level was existing in the cluster. The bench mark survey revealed that the average disease free laying (DFLs) brushing was ranging at 1.50 lakh with a nominal level of cocoon yield of $48.0 \mathrm{~kg} / 100 \mathrm{dfls}$ fetching a market value of Rs. 230/- per $\mathrm{kg}$ cocoon indicating the uneconomic venture of adopting sericulture by the farming community. Further, the cocoon yield as against the brushing of 1.50 lakh DFLs was also recorded in 72.0MT only generating a mere level of 10.29MT of raw silk/yr before the initiation of the CPP programme in the cluster. After initiating the CPP by involving all the modalities during 2009 to 2019 during XI \& XII five year plans the Bivoltine sericulture development to enviable levels and proved to be a workable and economically viable venture for the socio economic upliftment of the sericultural farming community raising the hopes of farming community raising
.com | Innovative Association 
their safety and security. Ten year CPP implementation efforts in implementing the bivoltine sericulture in $\mathrm{V}$. Kota cluster were presented in the Table 1\& Fig. 1,2,3).

It was observed that the Bivoltine DFLs brushing under the cluster was raised from the bench mark level (1.50 lakh) to 2.43 lakh (against the target of 2.25 lakh) during 2009-10, 2.61 vs 2.50 lakh during $2010-11,3.46$ vs 3.25 during $2011-12,9.00$ vs 8.75 lakh during 2012-13, 10.15 vs 10.0 during 2013-14, 11.55 vs 11.0 during 2014$15,13.3$ vs 12.6 during $2015-16,15.1$ vs 15.1 during 2016-17, 17.52 vs 17.8 during 2017$18,20.66$ vs 19.0 lakh during 2018-19 with a total of 78.1 lakh DFLs as against the targeted 76.5 lakh DFLs among the 30537.0 farmers, respectively in a span of 10 years period (2009-2019). The percentage of achievement in regard to the DFLs distribution was ranging from 98.4 to $108.8 \%$ against the targeted DFLs during 2009 to 2019 and 62.0 to $1277 \%$ over the benchmark level of DFLs brushing before the initiation of CPP. In regard to the cocoon yield per 100 DFLs also recorded significant increased levels ranging from $61.20 \mathrm{~kg}$ to $79.86 \mathrm{~kg}$ per 100 DFLs with an average yield improvement of $73.3 \mathrm{~kg}$ cocoon per 100 DFLs during 2009-19. Cocoon yield achievement was also noticed with significant level increase ranging from $27.50 \%$ to $66.38 \%$ as against the benchmark yield (48kg/100DFLs) with an average percentage of achievement with $52.71 \%$ during the 10 years period of CPP activity under the cluster. The increase DFLs brushing and cocoon yield/100DFLs may be due to the better adoption of critical technologies in imparting recommended manure and fertilizer applications and adopting soil analysis based amelioration of their mulberry gardens and effective disinfection of silkworm rearing houses by the use of improved disinfectants such as Asthra \& Serifit followed by the personal hygiene and better rearing management and the results are in agreement with the earlier studies conducted (Jaishankar and Dandin, 2005; Sudhakat et al., 2018). This study is also corroborated with the similar study conducted by other scientists in various clusters (Sreenivas et al., 2010; Himantharai et al., 2012; Sudhakar et al., 2019) Table 1 \& Fig. 1, 2. 
Table 1: Improvement of bivoltine sericulture among farmers on various aspects under CPP programme at V. Kota.

\begin{tabular}{|l|r|r|r|r|r|r|r|r|r|r|r|}
\hline \multicolumn{1}{|c|}{ Perticulars } & $\mathbf{2 0 0 9 -}$ & $\mathbf{2 0 1 0 -}$ & $\mathbf{2 0 1 1 -}$ & $\mathbf{2 0 1 2 -}$ & $\mathbf{2 0 1 3 -}$ & $\mathbf{2 0 1 4 -}$ & $\mathbf{2 0 1 5 -}$ & $\mathbf{2 0 1 6 -}$ & $\mathbf{2 0 1 7 -}$ & $\mathbf{2 0 1 8 -}$ & Total \\
& $\mathbf{2 0 1 0}$ & $\mathbf{2 0 1 1}$ & $\mathbf{2 0 1 2}$ & $\mathbf{2 0 1 3}$ & $\mathbf{2 0 1 4}$ & $\mathbf{2 0 1 5}$ & $\mathbf{2 0 1 6}$ & $\mathbf{2 0 1 7}$ & $\mathbf{2 0 1 8}$ & $\mathbf{2 0 1 9}$ & \\
\hline DFLs distribution target (lakh) & 2.25 & 2.50 & 3.25 & 8.75 & 10.00 & 11.00 & 12.6 & 15.10 & 17.80 & 19.00 & $\mathbf{7 6 . 5}$ \\
\hline Actual DFLs distributed (lakh) & 2.43 & 2.61 & 3.46 & 9.00 & 10.15 & 11.55 & 13.3 & 15.10 & 17.52 & 20.66 & $\mathbf{7 8 . 1}$ \\
\hline \% of Achievement & 108 & 104.4 & 106.5 & 102.9 & 101.5 & 105.0 & 105.2 & 105.6 & 98.4 & 108.8 & $\mathbf{1 0 4 . 6}$ \\
\hline \% Achievement over BM* & 62.0 & 74.0 & 130.7 & 500.0 & 576.7 & 670.0 & 786.7 & 906.7 & 1068.0 & 1277.3 & $\mathbf{6 0 5 . 2}$ \\
\hline Among no. of farmers & 650 & 705 & 815 & 3574 & 3250 & 3128 & 4632 & 5460 & 7124 & 10193 & $\mathbf{3 0 5 3 7 . 0}$ \\
\hline DFLs harvested (lakh) & 2.43 & 2.61 & 3.46 & 9.00 & 10.15 & 10.66 & 13.26 & 15.10 & 17.52 & 18.72 & $\mathbf{7 5 . 3}$ \\
\hline Yield of cocoons (Mt) & 148.8 & 173.3 & 229.0 & 586.8 & 688.7 & 724.9 & 957.5 & 1101.2 & 1290.3 & 1494.9 & $\mathbf{5 5 1 9 . 5}$ \\
\hline \% increase of yield over BM\# & 27.50 & 38.33 & 37.90 & 35.83 & 41.35 & 41.67 & 50.44 & 51.94 & 51.94 & 66.38 & 52.71 \\
\hline Cocoon yield (kg/100DFLs) & 61.20 & 66.40 & 66.19 & 65.20 & 67.85 & 68.0 & 72.21 & 72.93 & 73.65 & 79.86 & $\mathbf{7 3 . 3}$ \\
\hline \% increase of yield over BM\$ & 27.50 & 38.33 & 37.90 & 35.83 & 41.35 & 41.67 & 50.44 & 51.94 & 53.44 & 66.38 & $\mathbf{5 2 . 7 1}$ \\
\hline Raw silk Production (MT) & 20.11 & 24.76 & 32.72 & 85.11 & 98.38 & 103.63 & 136.79 & 156.91 & 184.29 & 213.59. & $\mathbf{5 8 1 . 6}$ \\
\hline \% increase Raw silk over BM ${ }^{\&}$ & 95.4 & 140.6 & 218.0 & 727.1 & 856.1 & 907.1 & 1229.3 & 1424.9 & 1691.0 & 1975.7 & $\mathbf{5 5 5 2 . 1}$ \\
\hline Avg. Matrket Rate (Rs) & 235.0 & 268.0 & 275.0 & 302.0 & 315.0 & 351.0 & 305.0 & 413.0 & 460.0 & 336.0 & $\mathbf{3 7 3 . 0}$ \\
\hline Increase over BM@ rate (\%) & 2.17 & 16.52 & 19.57 & 31.30 & 36.96 & 52.61 & 32.61 & 79.57 & 100.00 & 46.09 & $\mathbf{6 2 . 1 7}$ \\
\hline
\end{tabular}

BM = Bench Mark; BM* = Distribution @1,50,000DFLs/yr ; BM ${ }^{\#}=$ Cocoon yield @ 72.0MT; BM ${ }^{\S}=$ Yield @ 48kg/100DFLs; BM@ = Rate Rs.230/- per kg cocoon; BM\&= Raw silk production @ 10.29MT.

Due to the nerve pulling efforts of the CPP team consisting of Central and State Departmental field functionaries and the sincere, dedicated and committed efforts of the farming community during the CPP period of 2009-19 in a span of ten years the raw silk production was also enhanced from 20.11 MT to 213.59MT/year with an average silk production of 581.6MT for the period of 2009 to 2019. Due to the committed efforts of CPP implementation team production of quality cocoons could achieve due to which the farming community could fetch encouraging market value of the cocoons ranging from from Rs. 235/- to Rs. 336/- with an average market rate of Rs. 373/- as compared to the bench mark market rate of Rs. 230 before initiation of the CPP under the $\mathrm{V}$. Kota cluster (Table 1 \& Fig. 2). 


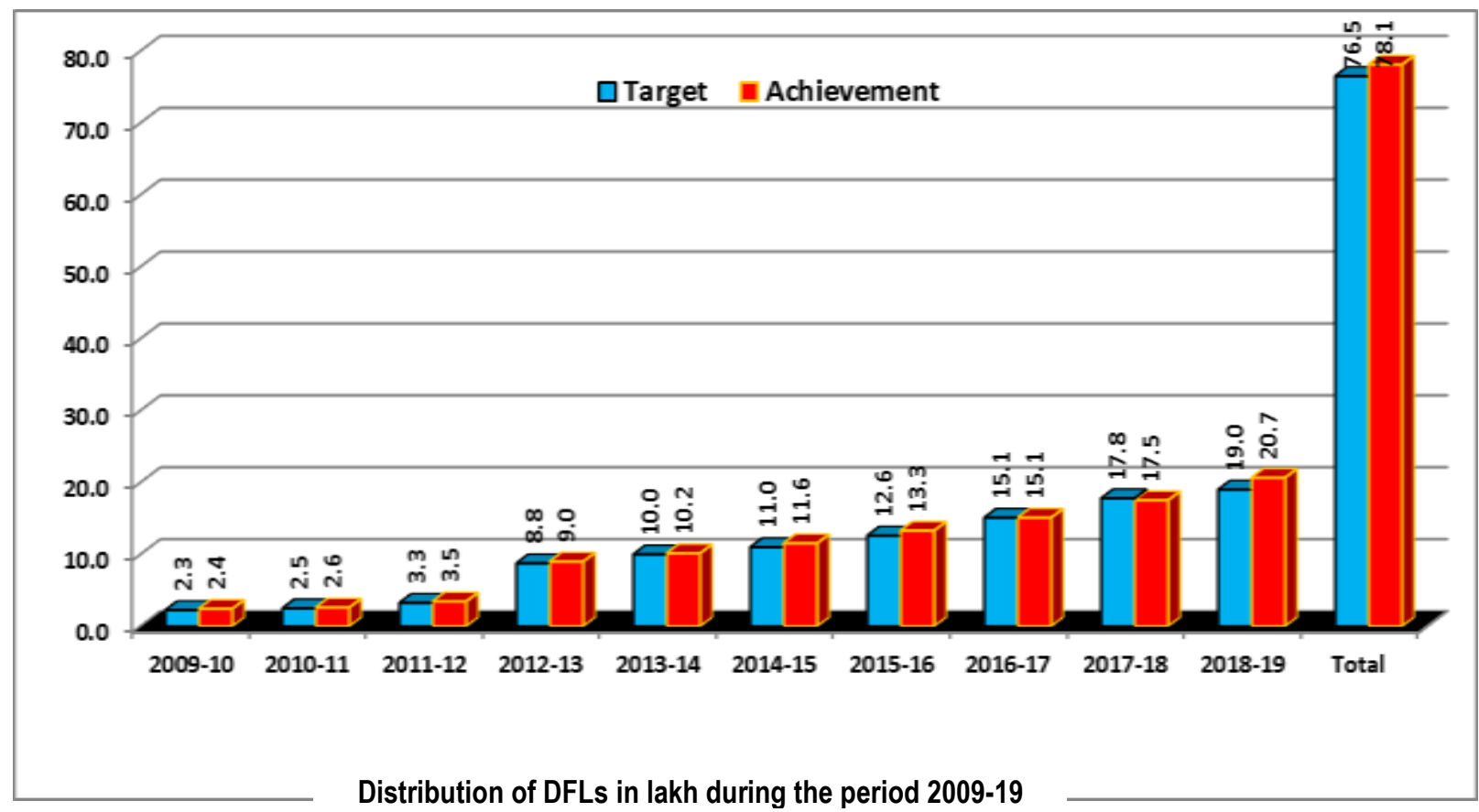

Fig. 1: Distribution of DFLs during 2009-19 against the target under the CPP, V. Kote cluster.

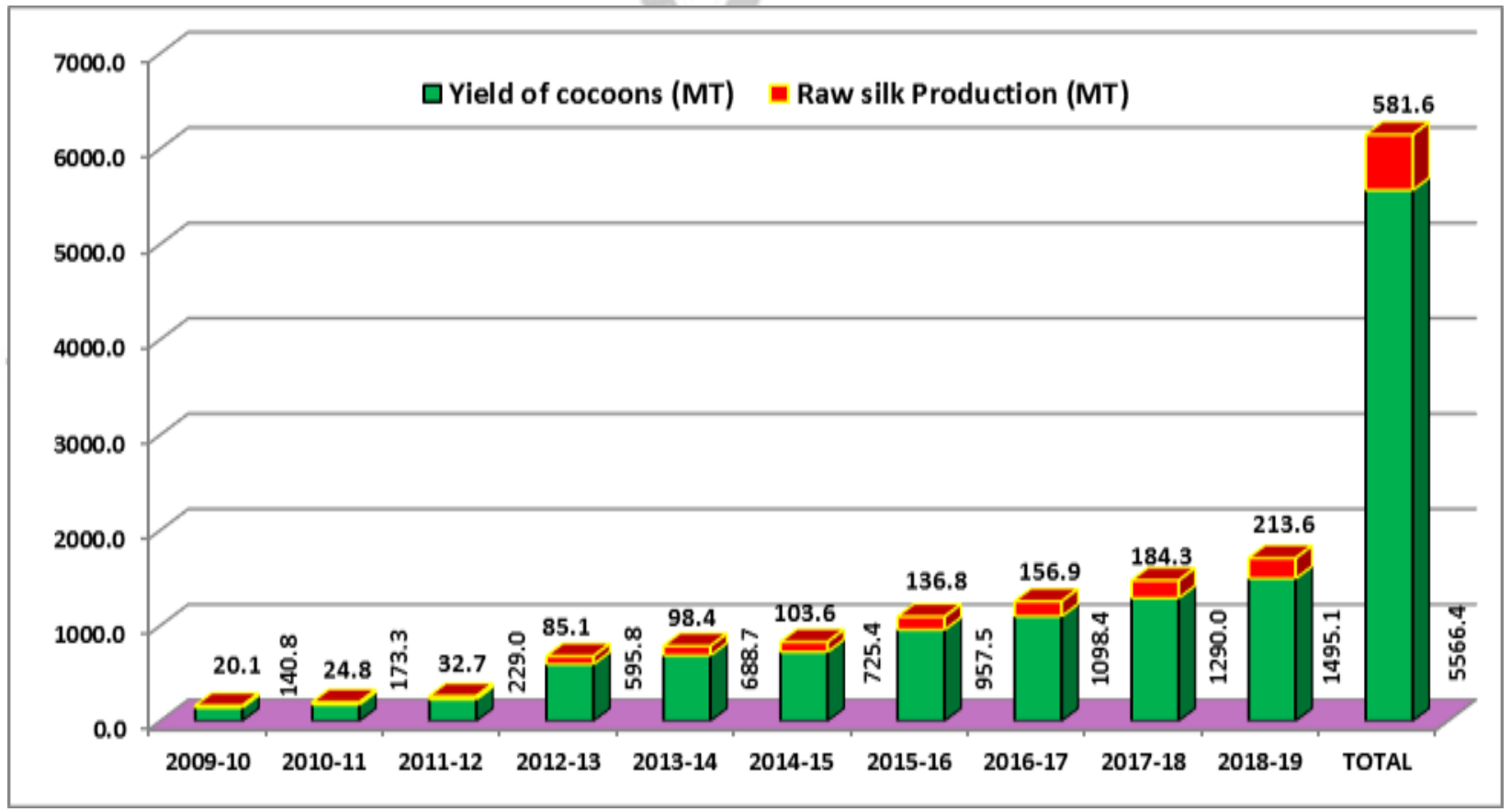

Fig. 2: Cocoon yield and raw silk production during 2009-19 under CPP, V. Kote cluster

The results of the study are in conformation with the study conducted by Singh et al. (1998) and Himantharaj et al. $(2011,2012)$. Due to intensive efforts such as imparting integrated nutrient management (INM) to improve farmers garden soils through green manuring by sowing sunhemp (Crotolaria juncea), dhaincha (Sesbania bispinosa), cowpea 
(Vigna unguiculata) and horse gram (Macrotyloma uniflorus) etc. in monsoon crops, use of integrated pest management (IPM) through the supply of biological control agents such as lady bird beetles (scymnus coccivora and Cryptolaemus montrouzieri) for tukra and Trichogramma chiloins for leaf roller to enhance quality mulberry leaf production. Whereas, biocontrol agents of Nesolynx thymus to control Uzi menace during silkworm rearing and Asthra and Serifit as effective rearing bed disinfectants for newly evolved silkworm rearing crops were played a major role in preventing the silkworm rearing crops failures and contributing in producing enhanced quality cocoon
(Table 1 \& Fig. 1). The improved rearing technologies popularized among the farming group also resulted in minimizing the cocoon melting percentage. Again it is proved that the prevention of silkworm rearing crops and reduction of defective cocoon percentage is also due to the result of the intensive efforts made by way of organizing several kinds of extension and communication programmes (ECPs) as detailed Table 2 and training programmes in sensitizing and generating awareness among the sericultural farming community on sorting of infectious and ill healthy bivoltine silkworms as stated by Himantharai et al. (2012) and Sudhakar et al. (2018).

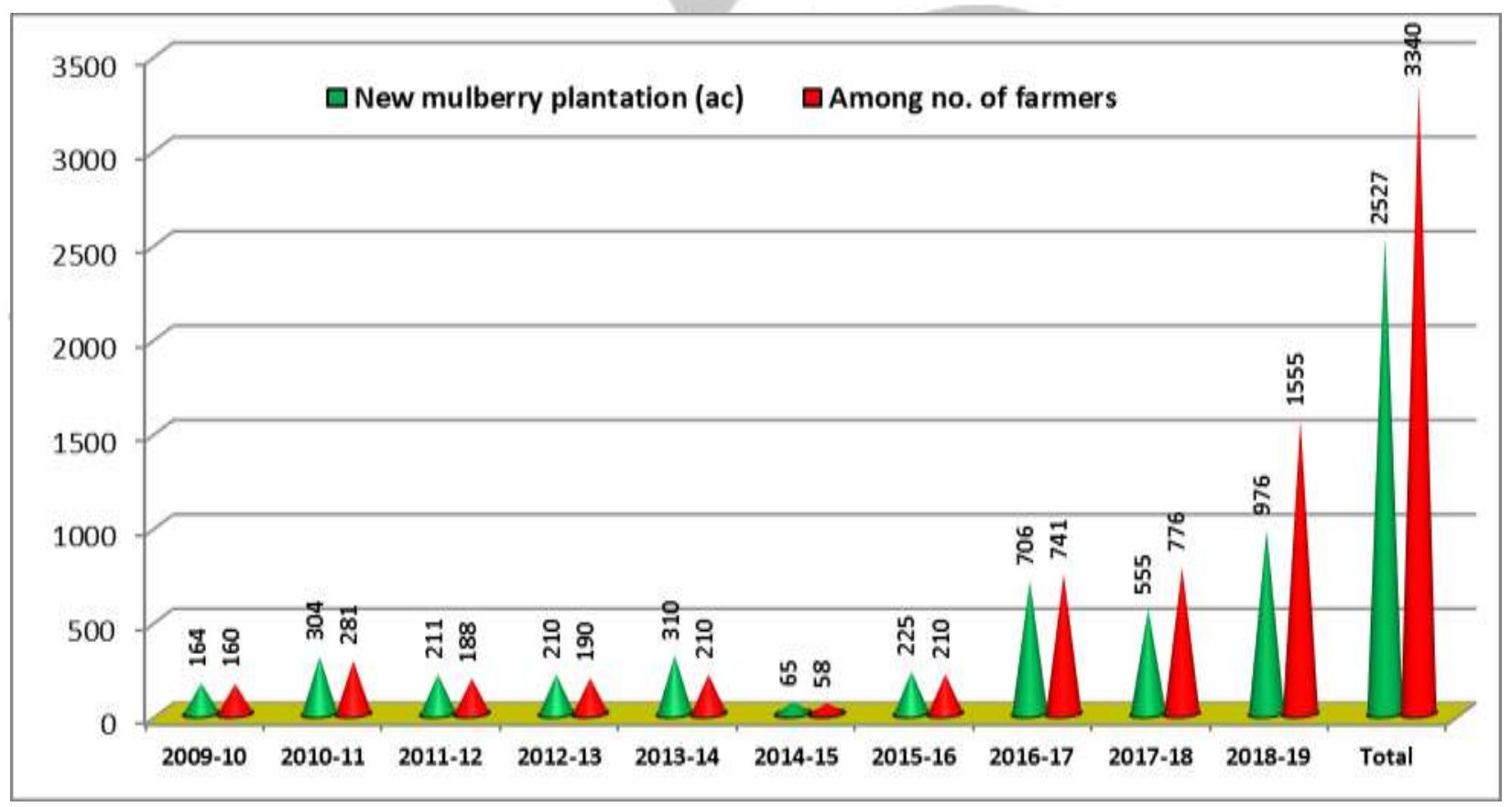

Fig. 3: New V1 mulberry plantation among the farmers under CPP, V. Kota cluster during 2009-19 
During the cluster promotion program under $\mathrm{V}$. Kota cluster the farmers were motivated in under taking new mulberry plantation, rearing house construction, infrastructural facilities of rearing and mulberry garden establishment by supporting under various Govt. subsidized programmes such as Catalytic Development Program (CDP), State Sericulture Development Program (SSDP), Mahathma Gandhi National Rural Employment Generation Program (MGNREGA), Rashtriya Krishi Vicas Yojana (RKVY) and Prime Minister Krishi Sichayee Yojana (PMKSY) and several central Sector Schemes (CSS) etc. During the program period 2009-2019 a total of 2527 acres of new mulberry plantation was undertaken among 3340 farmers of the cluster with high yielding mulberry varieties like $\mathrm{V} 1$ and $G 4$ in varied geometries such as paired row [(3'x2')5'], 3'x3' and 4'x4' in low bush form and wider spacing like 6' $\times 3^{\prime}, 8^{\prime} \times 4^{\prime}$ and as 10'X10' spacing in tree form with partial irrigation or micro irrigation (drip irrigation) conditions to combat with the prevailing drought stricken conditions in $\mathrm{V}$. Kota area under Chittoor District, Andhra Pradesh (Fig. 3). The new mulberry plantation was under taken as a part to achieve the vertical development of sericulture under the cluster. From the initiation of CPP new plantation of 164 acres among 160 farmers (2009-10), 304 acres among 281farmers (2010-11), 211 acres among 188 (2011-12), 210 acres among 190 farmers (2012-13), 310 acres among 210 farmers (2013-14), 65 acres among 58 farmers (2014-15), 225 acres among 210 farmers (2015-16), 706 acres among 741 farmers (2016-17), 555 acres among 776 farmers and 976 acres among 1555 farmers (2018-19), respectively was done with a total of 2527 acres among 3340 farmers during the period (Fig. 3).

During the cluster promotion program under V. Kota extensive Extension and Communication Programmes (ECPs) of various kinds were organized to sensitise the sericulturitst on various imporved technologies to generate awareness to improve their bivoltine sericulture. Duirng the period a total of 228 ECPs were organized among 12,768 serifarming communities and sensitized in enriching their working skills and technical knowhow for improved Bivoltine cocoon production. Enthusiastic participation of sericulturists' during ECPs under CPP, V. Kota cluster during 2009-2019 is also one of the main reasons for the successful implementation of CPP and achieving anticipated results in bivoltine sericultural developmental programme. During the CPP programme significant improvement in socio-economic conditions of the seri-farming community was noticed. The programme supported the farmers in adoption of bivoltine sericulture, earning encouraging money, investing the same for sericulture upliftment, purchasing land, vehicles, jewels, house hold articles, improved children education, conducting respectable rituals and becoming self sufficient in repayment of long pending borrowed loans (Table 2 \& Fig. 4).

Thus, the success of the programme can be attributed to co-ordinated and close working of different organizations involved in sericulture development such as REC, CSRTI, Mysore, National Silkworm 
Seed Organization (NSSO), Central Silk Technological Research Institute (CSTRI), Bangalore and State Sericulture Department at gross root level as well as higher level for common cause. Further, the cluster approach helped succeeding in pooling the resources such as man power, money, and infrastructural facilities etc., for conducting extension programmes effectively. The CPP offered how best the limited resources could be effectively utilized for promotion of bivoltine sericulture. Intensive ECPS undertaken under CPP, V. Kota and active participation of the sericultural fraternity (Fig. 5) are helped the farmers to accept and adopt the improved technologies and achieve the anticipated and encouraging results in improving bivoltine cocoon production levels significantly (Himantharaj et al. 2012; Vindhya et al., 2012; Sathyanarayana Raju, et al., 2014; Sudhakar et al., 2019). 
Table 2: ECPs of various kind organized and sensitized the sericulturists on various improved technologies for improving Bivoltine sericulture under cluster.

\begin{tabular}{|c|c|c|c|c|c|c|c|c|c|c|c|c|}
\hline Perticulars & $\begin{array}{l}\text { Prog no./ } \\
\text { Farmers }\end{array}$ & $\begin{array}{l}2009- \\
2010 \\
\end{array}$ & $\begin{array}{r}2010- \\
2011\end{array}$ & $\begin{array}{l}2011- \\
2012 \\
\end{array}$ & $\begin{array}{r}2012- \\
2013 \\
\end{array}$ & $\begin{array}{r}2013- \\
2014 \\
\end{array}$ & $\begin{array}{l}2014- \\
2015 \\
\end{array}$ & $\begin{array}{r}2015- \\
2016 \\
\end{array}$ & $\begin{array}{l}2016- \\
2017 \\
\end{array}$ & $\begin{array}{l}2017- \\
2018 \\
\end{array}$ & $\begin{array}{l}2018- \\
2019\end{array}$ & Total \\
\hline \multirow{2}{*}{ Group Discussions } & No & 15 & 20 & 10 & 6 & 6 & 3 & 9 & 6 & 6 & 6 & 87 \\
\hline & Farmers & 487 & 796 & 321 & 217 & 245 & 146 & 482 & 205 & 256 & 264 & 3419 \\
\hline \multirow{2}{*}{ Farmers Day } & No & -- & -- & -- & -- & -- & -- & 2 & 2 & 4 & 4 & 12 \\
\hline & Farmers & -- & -- & -- & -- & -- & -- & 123 & 119 & 252 & 270 & 764 \\
\hline \multirow{2}{*}{ Field Days } & No & 2 & 6 & 7 & 4 & 2 & 2 & 2 & 1 & 1 & 1 & 28 \\
\hline & Farmers & 131 & 439 & 372 & 236 & 110 & 169 & 175 & 130 & 130 & 145 & 2037 \\
\hline \multirow{2}{*}{$\begin{array}{l}\text { Awareness } \\
\text { programme }\end{array}$} & No & 5 & 9 & 9 & 5 & 3 & 3 & 2 & 1 & 3 & 1 & 41 \\
\hline & Farmers & 306 & 434 & 432 & 309 & 210 & 220 & 210 & 160 & 410 & 144 & 2835 \\
\hline \multirow{2}{*}{ Farmers training } & No & -- & -- & -- & -- & -- & -- & -- & -- & -- & -- & 0 \\
\hline & Farmers & -- & -- & -- & -- & -- & -- & -- & -- & -- & -- & 0 \\
\hline \multirow{2}{*}{$\begin{array}{l}\text { Farmers } \\
\text { Study Tours }\end{array}$} & No & 1 & 4 & 2 & -- & 2 & 1 & -- & -- & -- & -- & 10 \\
\hline & Farmers & 15 & 55 & 9 & -- & 30 & 49 & -- & -- & -- & -- & 158 \\
\hline \multirow{2}{*}{$\begin{array}{l}\text { Enlightenment } \\
\text { programmes }\end{array}$} & No & 1 & 1 & 1 & 1 & 1 & 2 & 1 & -- & -- & -- & 8 \\
\hline & Farmers & 275 & 339 & 279 & 186 & 175 & 377 & 210 & -- & -- & -- & 1841 \\
\hline \multirow{2}{*}{ Film Shows } & No & -- & -- & 10 & 6 & 2 & 2 & -- & -- & -- & -- & 20 \\
\hline & Farmers & -- & -- & 288 & 198 & 165 & 120 & -- & -- & -- & -- & 771 \\
\hline \multirow{2}{*}{ Exhibitions } & No & 2 & -- & 4 & 4 & -- & 1 & -- & -- & -- & -- & 11 \\
\hline & Farmers & 84 & -- & 141 & 163 & -- & 76 & -- & -- & -- & -- & 464 \\
\hline \multirow{2}{*}{ Demonstrations } & No & 6 & 5 & -- & -- & -- & -- & -- & -- & -- & -- & 11 \\
\hline & Farmers & 289 & 190 & -- & -- & -- & -- & - & -- & -- & -- & 479 \\
\hline \multirow{2}{*}{ Total } & ECPs & \multicolumn{2}{|c|}{\begin{tabular}{l|l}
32 & 45 \\
\end{tabular}} & 43 & 26 & 16 & 14 & 16 & 10 & 14 & 12 & 228 \\
\hline & Farmers & 1587 & 2253 & 1842 & 1309 & 935 & 1157 & 1200 & 614 & 1048 & 823 & 12768 \\
\hline
\end{tabular}

*ECPs= Extension and Communication Programmes.

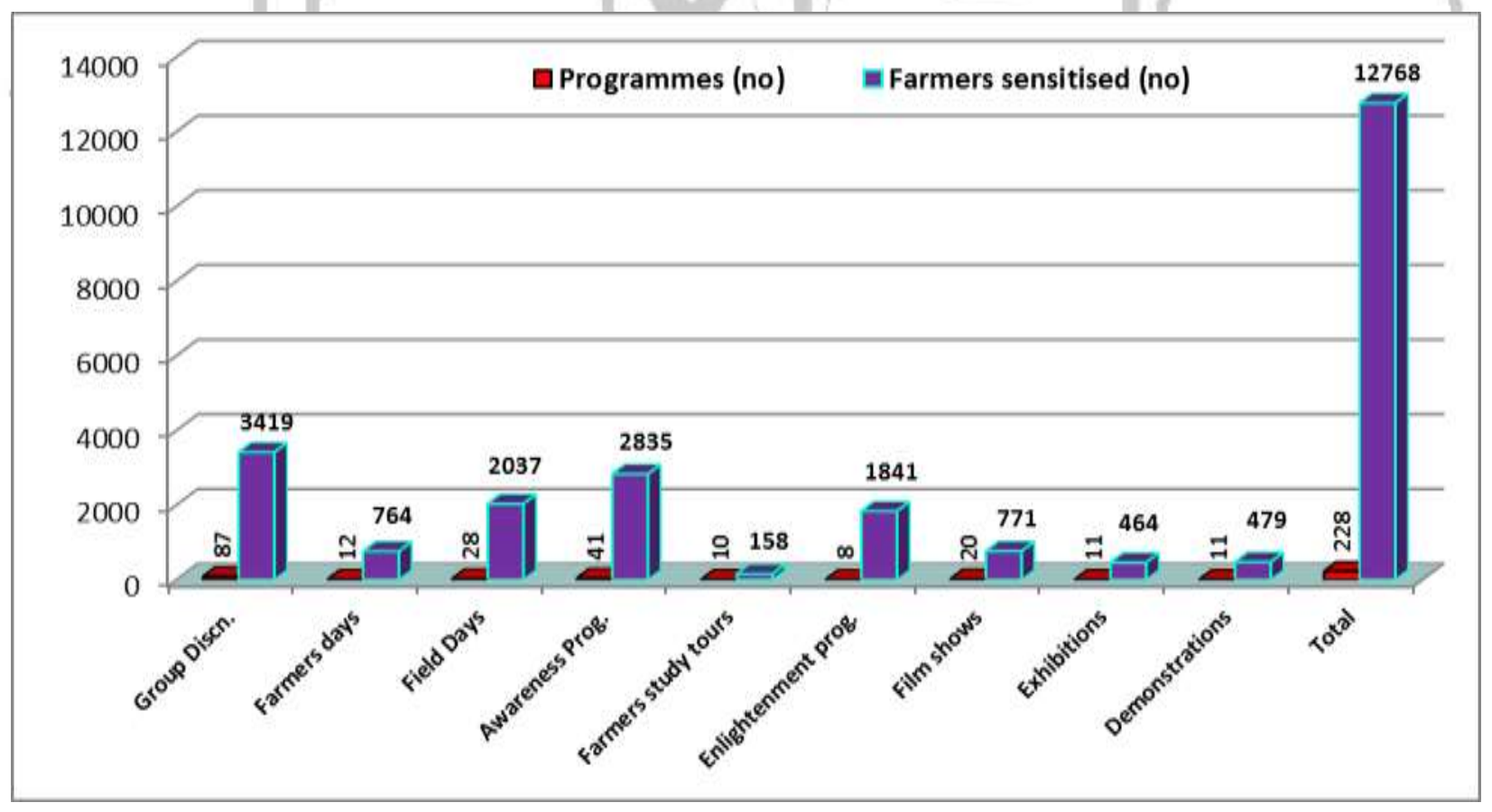

Fig. 4: ECPs organized and sensitization of the sericulturitsts under the CPP, V. Kota. 


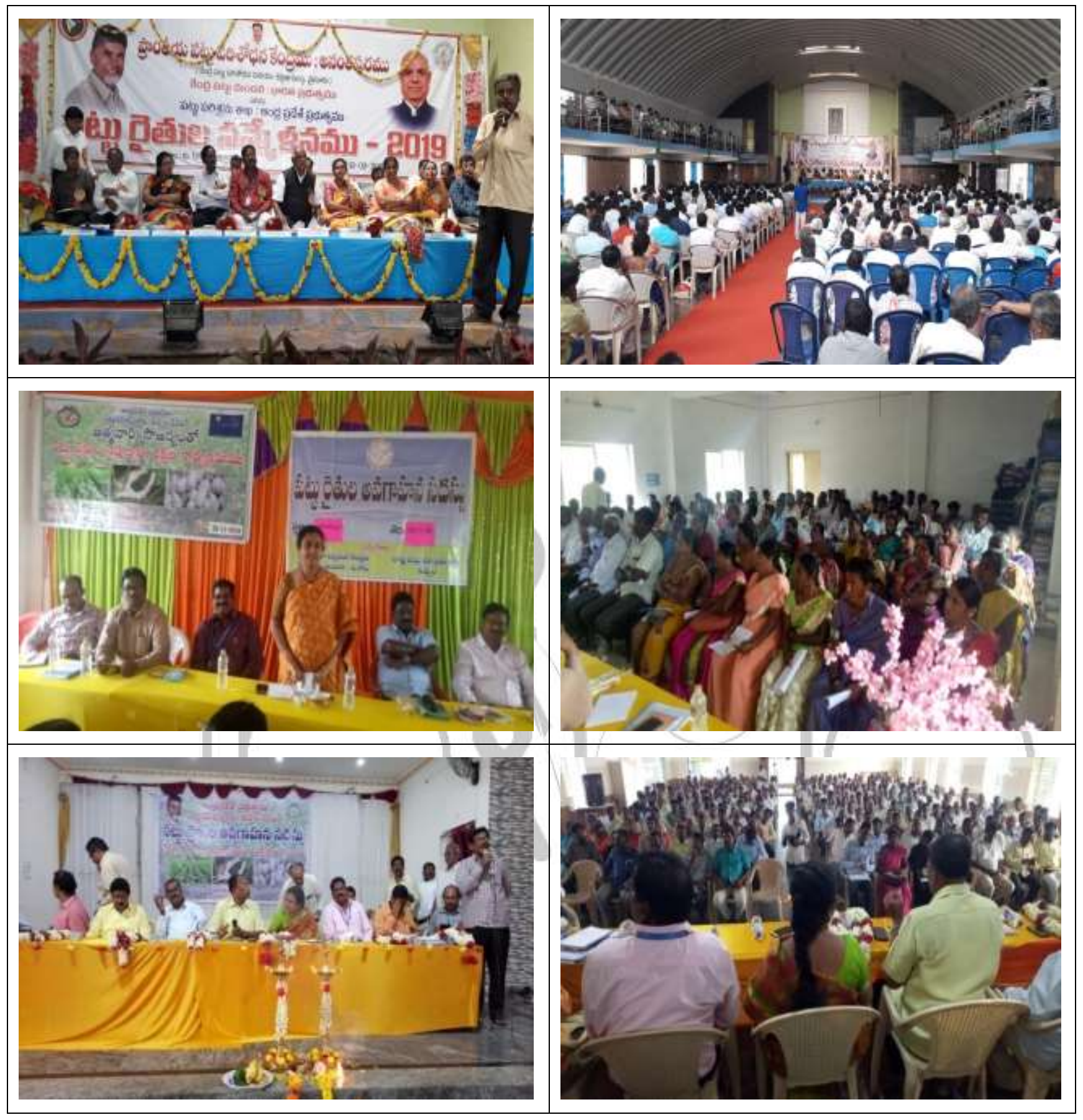

Fig. 5: Sensitization of sericultural farmers on various improved technologies during ECPs organized under V. Kota cluster. 


\section{CONCLUSION}

Therefore, with the above findings the study can be concluded that the improvement indicates the success of CPP programme during XI \& XII- five year plans at $V$. Kota during 2009-19 is nothing but intensive adoption of integrated technology in cluster approach is one of the remedy for attaining sustainability of sericulture. This approach is with suitable refinement can be adopted elsewhere in the sericulture areas of the country to ensure higher rate of adoption of technologies, higher returns from sericulture and promotion of bivoltine sericulture during future course of five year plans. Further, it is essential to continue the intensive bivoltine promotion programmes of this kind in future in the new clusters established under CPP so as to make our country self sufficient and self reliable in quality bivoltine silk production thereby projecting India as one of the potential bivoltine silk producers at international market.

\section{ACKNOWLEDGEMENT}

The authors are indebted to the Central Silk Board, Ministry of Textiles and its Scientific and Technical fraternity, Joint Director, TSC in-charges, and range Officials of Department of Sericulture (DOS), Govt. of Andhra Pradesh, Ananthapur \& Chittoor for their help and co-operation for the study.

\section{REFERENCES}

Dandin, S.B., Jayaswal, J. and Giridhar, K. 2003. Handbook of Sericulture Technologies. Central Silk Board, Bangalore, India. Pp. 1-259.

Himantharaj, M.T., Srinivas, G., Gnanasekharan, P. and Vindhya, G.S. 2007. Impact of JICA programme on sericulture development in Tamil Nadu. MANAGE Extension Research Review. VIII (1): 19-26.

Himantharaj M.T., Umesha, A., Sreenivas, B.T and Jaishankar. 2011. Impact of rotary mountages on cocoon and reeling parameters in silkowrm Bombyx mori L. at farmers level. Green Farming. 2 (2): 239241.

Himantharaj, M.T., Umesha, A., Jaishankar and Quadri, S.M.H. 2012. Cluster promotion programme and its impact on cocoon production and socio-economic status of sericulturists. Green Farming, 3(5): 597-600.

Jaishankar and Dandin, S.B. 2005. Socioeconomic attributes in the adoption of improved sericultural technologies by farmers in Kolar district. Indian J. of Seric. 47: 155-160.

Qadri, S.M.H. 2012. Role of Cluster Promotion Programme (CPP). Brain Storming Workshop on CPP, RKVY and MGNREGS, 30-31 st Jan, 2012, CSRTI, Mysore, Karnataka.

Sathyanarayana Raju, Ch., Prasad, G.V., Mogili, T., Kasi Reddy, B., Reddy, M.P., Rao., M.V., Purushotha, S., Sivarami Reddy, N., Vindhya, G.S. and Qadri, S.M. 2014. Impact of cluster promotion programme on 
bivoltine sericulture in Andhra Pradesh. Indian Silk., 4(52old) no. 10-1 1: 4-8.

Sreenivas, B.T., Umesha, A., Humantharaj, M.T., Jaishankar, Qhadri,S.M.H and Kamble,C.K. 2009. Impact of IVLP on mulberry leaf and cocoon yield at farmers level. Journal of Agric. Ext. Management.10(2):93-98.

Sreenivas, B.T., Umesha, A., Humantharaj, M.T., Jaishankar, Qhadri, S.M.H and Kamble, C.K. 2010. Institute Village Linkage Programme (IVLP) in sericulture and its impact on productivity and adoption of sericulture technologies at farmers level. J. Exp. Zool. India, 13(1): 143-146.

Sudhakar, P., Krishnappa, B.L., Jalaja S. Kumar. and Sivaprasad,.V. 2018. Impact of Cluster Promotion Programme (CPP) on the Bivoltine cocoon production under Shapur cluster, Kolar, Karnataka. Green Farming, Vol 9(1): 129-133.

Sudhakar, P., Venugopal, A., Vidyunmala, S., Venkataramanappa, T., Vijaya Naidu, B. and Teotia, R.S. 2019. Bivoltine Sericulture Development in Penukonda, Ananthapur district of Andhra Pradesh through cluster promotion programme (CPP). Int. J. of Pure \& App. Biosci. 7(2): 513-521.

Vindhya, G.S. 2012. Impact of Cluster Promotion Programme on popularization of bivoltine sericulture in South India. National Workshop on Promotion of Sericulture for Sustainable income, 17-18 th March, 2012, Annamalai University, Chidambaram, Tamil Nadu. 